\title{
Penerapan DASH (Dietary Approach to Stop Hypertension) pada Penderita Hipertensi
}

\author{
Bagas Mukti \\ Mahasiswa Pendidikan Dokter, Fakultas Kedokteran Universitas Lampung \\ e-mail: bagas.mukti17@gmail.com
}

\begin{abstract}
Hypertension is a manifestation of cardiovascular hemodynamic disorders whose causes are multifactorial. The prevalence of hypertension in Indonesia alone in 2018 increases from 2013 and the increase is 8.3\%. Someone said to be hypertensive if blood pressure is above or equal to $140 / 90 \mathrm{mmHg}$ and must be persistent. Hypertension itself is still the highest cause of death and can cause serious complications such as stroke, ischemic heart disease, kidney failure, retinopathy and so on. There are many guidelines that explain how management of therapy to reduce high blood pressure. There are two ways to manage hypertension sufferers, namely pharmacological therapy (Diuretics, $\beta$-blockers, ACE Inhibitors, Angiotensin Receptor Blockers (ARB), Calcium-channel blockers (CCB) and so on) and non-pharmacological therapy by modifying lifestyles such as regular exercise, reduce alcohol consumption, stop smoking, and lose weight, reduce salt consumption by adapting the DASH (Dietary Approaches to Stop Hypertension) diet. The DASH diet adopts a diet rich in vegetables, fruits, milk and low-fat or low-fat dairy products, whole grains, fish, poultry, nuts and this diet also contains a little sodium, sweet foods, sugar, fat, and red meat. In a meta-analysis and systematic review of randomized controlled trials (RCTs), revealed that the application of the DASH diet in hypertensive patients can reduce systolic blood pressure by $6.74 \mathrm{mmHg}$ and diastolic blood pressure by $3.54 \mathrm{mmHg}$. Another metaanalysis of RCTs has shown that applying this diet can reduce weight in obese patients by $1.42 \mathrm{~kg}$ within 8-24 weeks. So that the DASH diet is very useful for patients with hypertension.
\end{abstract}

Keywords: hypertension; DASH.

\begin{abstract}
ABSTRAK
Hipertensi merupakan suatu manifestasi dari gangguan hemodinamik kardiovaskular yang penyebabnya multifactor. Prevalensi penderita hipertensi di Indonesia sendiri pada tahun 2018 meningkatkan dari tahun 2013 dan peningkatan tersebut sebesar $8,3 \%$. Seseorang dikatakan hipertensi jika tekanan darah diatas atau sama dengan 140/90 $\mathrm{mmHg}$ dan harus persisten. Hipertensi sendiri masih menjadi penyebab kematian tertinggi dan dapat menyebabkan komplikasi yang serius seperti stroke, penyakit jantung iskemik, gagal ginjal, retinopati dan sebagainya. Ada banyak guidelines yang menjelaskan bagaimana manajemen terapi untuk mengurangi tekanan darah tinggi. Ada dua cara untuk mentatalaksana penderita hipertensi, yaitu dengan terapi farmakologis (Diuretik, $\beta$-blocker, ACE Inhibitor, Angiotensin Receptor Blockers (ARB), Calcium-channel blocker (CCB) dan sebagainya) dan terapi non farmakologi dengan memodifikasi gaya hidup seperti olahraga teratur, mengurangi konsumsi alcohol, menghentikan rokok, serta menurunkan berat badan, mengurangi konsumsi garam dengan cara mengadaptasi diet DASH (Dietary Approaches to Stop Hypertension). Diet DASH menerapkan pola makan yang kaya akan sayuran, buah-buahan, susu dan produk-produk susu tanpa lemak atau rendah lemak, biji-bijian, ikan, unggas, kacang-kacangan dan diet ini juga mengandung sedikit natrium, makanan manis, gula, lemak, dan daging merah. Pada penelitian meta-analisis dan sistematik review dari randomized controlled trials (RCTs), mengungkapkan bahwa penerapan diet DASH pada pasien hipertensi dapat menurunkan tekanan darah sistolik sebesar $6,74 \mathrm{mmHg}$ dan tekanan darah diastolic sebesar 3,54 mmHg. Studi meta-analisis lain dari RCTs membuktikan bahwa dengan penerapan diet ini dapat menurunkan berat badan pada pasien yang mengalami obesitas sebesar 1,42 kg dalam waktu 8-24 minggu. Sehingga diet DASH ini sangat bermanfaat untuk diterapkan pada pasien hipertensi.
\end{abstract}

Kata kunci: hipertensi; DASH.

\section{PENDAHULUAN}

Hipertensi merupakan salah satu penyakit degeneratif yang mempunyai tingkat morbiditas dan mortilitas yang tinggi. ${ }^{(1)}$ Penyakit ini dapat mengganggu fungsi organ lain, terutama organ-organ vital seperti jantung dan ginjal. $^{(2)}$ Faktor resiko yang paling penting untuk terjadinya penyakit jantung coroner, stroke, penyakit ginjal, dan retinopati disebabkan karena hipertensi. $^{(3)}$

Menurut data Riskesdas 2018, prevalensi hipertensi di Indonesia masih tinggi, yaitu $34,1 \%$ yang didapat berdasarkan hasil pengukuran pada penduduk umur $\geq 18$ tahun. Terdapat peningkatan $8,3 \%$ dari $25,8 \%$ pada tahun 2013 menjadi 34,1\% pada tahun 2018 . 
Peningkatan ini lebih rendah jika dibandingkan data Riskesdas pada tahun 2007-2013, yaitu sebesar 9,5\%. Prevalensi tertinggi berada di provinsi Kalimantan Selatan $(44,1 \%)$ dan hasil ini menggeser prevalensi tertinggi pada tahun 2013, yaitu provinsi Bangka Belitung (30,9\%). ${ }^{(4)}$

Sampai saat ini hipertensi masih menjadi tantangan besar di Indonesia karena hipertensi merupakan kondisi yang sering ditemukan pada pelayanan kesehatan tingkat pertama (primer) sehingga perlu dilakukan penatalaksanaan yang adekuat. ${ }^{(5)}$ Terapi pada hipertensi dapat berupa terapi farmakologis dengan mengonsumsi obat-obatan seperti Diuretik, $\beta$-blocker, ACE Inhibitor, Angiotensin Receptor Blockers (ARB), Calcium-channel blocker (CCB) dan sebagainya. Akan tetapi, jika obat-obatan tersebut diberikan pada kelompok usia lansia yang telah mengalami penurunan fungsi organ dapat menimbulkan berbagai efek samping salah satunya ginjal, sehingga diperlukan terapi non farmakologis juga. ${ }^{(6)}$

Seventh report of the joint national committee on prevention, detection, evaluation, and treatment of high blood pressure (JNC7) merekomendasikan modifikasi gaya hidup sebagai terapi non farmakologis yang penting pada hipertensi. ${ }^{3}$ National Institute of Health dan National Heart, Lung, and Blood Institute (2006) merekomendasikan modifikasi gaya hidup dengan pengaturan diet makan harian berupa rencana makan harian DASH (Dietary Approach to Stop Hypertension). DASH merupakan bentuk terapi non farmakologis hipertensi dalam bentuk diet makanan harian yang tinggi srat dan rendah lemak. Diet ini didesain mengikuti panduan pemeliharaan kesehatatan jantung untuk membatasi lemak jenuh dan kolesterol, serta membatasi natrium. Pola asupan makanan pada diet ini berperan dalam pencegahan dan terapi pada penyakit hipertensi. ${ }^{(7)(8)}$

\section{PEMBAHASAN}

Darah didalam tubuh diperlukan untuk media pengangkut oksigen serta zat lain yang diperlukan untuk kehidupan sel-sel di dalam tubuh dan tekanan darah merupakan daya yang diperlukan agar darah dapat mengalir dalam pembuluh darah untuk beredar mencapai seluruh jaringan tubuh manusia. ${ }^{(9)}$ Tekanan darah dipengaruhi oleh tahanan pembuluh darah tepi atau total peripheral resistance (TPR) terhadap aliran darah yang mengalir dan volume cairan yang mengisi pembuluh darah atau cardiac output (CO) yang besarnya ditentukan oleh curah jantung. Sehingga bila terjadi peningkatan elastisitas pembuluh dan volume darah akan menyebabkan peningkatan tekanan darah dan begitu sebaliknya. ${ }^{(10)(11)}$ Tekanan darah dibedakan menjadi tekanan darah sistolik dan tekanan darah diastolic. Tekanan darah sistolik merupakan tekanan tertinggi ketika otot jantung berkontraksi, sedangkan tekanan darah diastolic merupakan tekanan terendah saat otot jantung relaksasi. ${ }^{(12)}$

Hipertensi atau tekanan darah tinggi merupakan suatu manifestasi gangguan keseimbangan hemodinamik sistem kardiovaskular yang memiliki patofisiologi multifactor, sehingga tidak dapat diterangkan dengan satu mekanisme tunggal. ${ }^{(13)}$ Hipertensi menyangkut banyak faktor, yaitu faktor genetic, lingkungan dan pusat-pusat regulasi hemodinamik. Jika disederhanakan, hipertensi merupakan interaksi antara cardiac output (CO) dan total peripheral resistance (TPR). ${ }^{(14)}$ Hipertensi memiliki angka kesepakatan berdasarkan bukti klinis (evidence based) atau berdasarkan epidemiologi studi meta analisis maupun berdasarkan consensus. Dikatakan hipertensi jika tekanan darah di atas atau sama dengan 140/90 $\mathrm{mmHg}$ dan harus persistens. Persistensi peningkatan tekanan darah di atas 140/90 $\mathrm{mmHg}$ harus terbukti, sebab bisa saja peningkatan tekanan darah tersebut bersifat transient atau hanya merupakan peningkatan diurnal dari tekanan darah yang normal sesuai siklus sirkadian (pagi dan siang tekanan darah meningkat, malam hari tekanan darah menurun, tetapi masih dalam variasi batas normal). ${ }^{(15)}$ Guideline yang paling umum digunakan untuk menentukan tingkatan hipertensi yaitu Seventh Joint National Committee (JNC7) (Tabel 1). ${ }^{(3)}$

Tabel 1. Klasifikasi Tekanan Darah Berdarkan JNC 7

\begin{tabular}{|c|c|c|}
\hline $\begin{array}{c}\text { Klasifikasi } \\
\text { Tekanan Darah }\end{array}$ & $\begin{array}{c}\mathrm{SBP} \\
\mathrm{mmHg}\end{array}$ & $\begin{array}{l}\mathrm{DBP} \\
\mathrm{mmHg}\end{array}$ \\
\hline Normal & $<120$ & dan $<80$ \\
\hline Prehipertensi & $120-139$ & atau $80-89$ \\
\hline $\begin{array}{c}\text { Hipertensi Grade } \\
1\end{array}$ & $140-159$ & atau 90-99 \\
\hline $\begin{array}{l}\text { Hipertensi Grade } \\
2\end{array}$ & $\geq 160$ & atau $\geq 100$ \\
\hline
\end{tabular}

Secara linier, peningkatan tekanan darah dikaitkan dengan peningkatan risiko penyakit kardiovaskular (Cardiovascular Disease). Peningkatan systolic blood pressure (SBP) memiliki keterkaitan terkuat terhadap penyakit kardiovaskular, meskipun komponen tekanan darah yang lainnya juga memiliki kaitan dengan penyakit kardiovaskular termasuk diastolic blood pressure (DBP), tekanan nadi, tekanan darah arteri rata-rata, dan variabilitas tekanan darah. Mulai dari tekanan darah 115/75 $\mathrm{mmHg}$, setiap peningkatan SBP $20 \mathrm{mmHg}$ dan/atau peningkatan DBP $10 \mathrm{mmHg}$ memiliki risiko kematian dua kali lipat 
dari penyakit stroke, penyakit jantung, atau penyakit pembuluh darah lainnya. ${ }^{(16)}$

Hipertensi masih menjadi penyebab kematian tertinggi di dunia. Pada jangka waktu lama bila hipertensi tidak dapat turun stabil pada kisaran normo tensi maka dapat merusak organ-organ terkait. Komplikasi hipertensi dapat mengenai beberapa organ target seperti pada jantung (penyakit jantung iskemik, hipertrofi ventrikel kiri, gagal jantung), otak (stroke), ginjal (gagal ginjal), mata (retinopati), dan artei perifer (klaudikasio intermiten). Kerusakan organ-organ tersebut bergantung pada tingginya tekanan darah yang dialami pasien dan berapa lama tekanan darah tinggi tersebut tidak diobati dan tidak terkontrol. ${ }^{(17)}$

Manajemen atau tatalaksana untuk menurunkan tekanan darah melalui dua cara yang saling berkesinambungan dan tidak bisa dipisahkan agar dapat menurunkan tekanan darah secara optimal, yaitu dengan tatalaksana non farmakologis atau dengan modifikasi gaya hidup dan dengan tatalaksana farmakologis berdasarkan algoritma yang berlaku pada setiap guideline. Modifikasi gaya hidup sehat telah banyak terbukti dapat menurunkan tekanan darah, dan juga secara umum sangat menguntungkan dalam menurunkan risiko permasalahan kardiovaskular. Pada pasien yang menderita hipertensi derajat 1 dan tanpa faktor risiko kardiovaskular lain, maka strategi modifikasi gaya hidup sehat merupakan tatalaksana tahap awal yang harus dijalani setidaknya selama 4-6 bulan. Bila setelah itu tidak didapatkan penurunan tekanan darah yang diharapkan atau didapatkan faktor risiko kardiovaskular yang lain, maka dianjurkan untuk memulai terapi farmakologi. ${ }^{(6)}$

Modifikasi gaya hidup yang dianjurkan oleh JNC 7 dan oleh beberapa guidelines lain. ${ }^{(6)(16)}$

1. Penurunan berat badan. Rekomendasi penurunan berat badan meliputi pengurangan asupan kalori dan juga meningkatkan aktivitas fisik. Memperbanyak asupan sayuran dan buah-buahan dapat memberikan manfaat lain selain penurunan tekanan darah seperti menghindari diabetes dan dislipidemia. Penurunan berat badan dapat mengurangi tekanan darah sistolik 5-20 $\mathrm{mmHg} /$ penurunan $10 \mathrm{~kg}$. Ukuran pinggang yang dianjurkan yaitu pria $<94 \mathrm{~cm}$ dan wanita $<80 \mathrm{~cm}$, indeks massa tubuh $<25 \mathrm{~kg} / \mathrm{m}^{2}$.

2. Menerapkan pola makan DASH (Dietary Approaches to STOP Hypertension) dapat menurunkan tekanan darah sistolik 8-14 $\mathrm{mmHg}$. Diet ini menganjurkan lebih banyak makan buah, sayur-sayuran, dan produk susu rendah lemak dengan kandungan lemak jenuh dan total lebih sedikit, kaya potassium dan calcium.

3. Mengurangi asupan garam. Rekomendasikan makanan rendah garam sebagai bagian dari pola makan sehat. Dianjurkan untuk asupan garam tidak melebihi 2 gr/ hari. Pengurangan garam harian dapat menurunkan tekanan darah sistolik 2-8 mmHg. Pada pasien hipertensi derajat $\geq 2$, diet rendah garam juga bermanfaat untuk mengurangi dosis obat hipertensi.

4. Olah raga atau aktivitas fisik. Melakukan aktivitas fisik intensitas sedang secara teratur sebanyak 3060 menit/ hari, minimal 3 hari/ minggu, dapat menurunkan tekanan darah sistolik 4-9 mmHg.

5. Mengurangi konsumsi alcohol. Pembatasan konsumsi alcohol dapat menurunkan tekanan darah sistolik 2-4 mmHg. Maksimum 2 minuman standard/ hari (1 oz atau $30 \mathrm{ml}$ ethanol; misalnya bir $24 \mathrm{oz}$, wine $10 \mathrm{oz}$, atau $3 \mathrm{oz}$ 80-proof whiskey) untuk pria, dan 1 minuman standard/ hari untuk wanita. Konsumsi alcohol lebih dari 2 gelas per hari pada pria atau 1 gelas per hari pada wanita dapat meningkatkan tekanan darah. Maka dengan demikian membatasi atau menghentikan konsumsi alcohol akan sangat membantu dalam menurunkan tekanan darah.

6. Berhenti merokok. Meskipun sampai saat ini merokok belum terbukti dapat menurunkan tekanan darah, tetapi merokok merupakan salah satu faktor risiko utama penyakit kardiovaskular sehingga anjuran berhenti merokok untuk mengurangi risiko kardiovaskular secara keseluruhan.

Diet DASH (Dietary Approaches to Stop Hypertension) merupakan suatu modifikasi gaya hidup untuk penderita hipertensi dengan memakan makanan yang kaya akan buah-buahan, sayuran, susu dan produk-produk susu tanpa lemak atau rendah lemak, biji-bijian, ikan, ungags, kacang-kacangan. Diet DASH juga mengandung sedikit natrium, makanan manis, gula, lemak, dan daging merah. Desain dari diet DASH ini juga mengandung lebih sedikit lemak jenuh, lemak trans, dan kolesterol serta kaya akan nutrisi yang berhubungan dengan penurunan tekanan darah, terutama kalium, magnesium, kalsium, protein, dan serat. ${ }^{(7)}$

Diet DASH tidak memerlukan makanan khusus ataupun resep yang sulit untuk diikuti. Diet ini hanya membutuhkan sejumlah porsi harian dari berbagai kelompok makanan. Jumlah porsi harian tergantung pada jumlah kalori yang dibutuhkan setiap harinya. Tingkat kalori tergantung pada usia, terutama seberapa banyak aktifitas fisik yang dilakukan setiap hari. Tingkat aktivitas fisik dibagi menjadi tiga kategori, yaitu:

1. Tidak bergerak, hanya melakukan aktivitas fisik ringan yang merupakan bagian dari rutinitas sehari-hari; 
2. Cukup aktif, melakukan aktivitas fisik yang setara dengan berjalan kaki sekitar 1 hingga 3 mil sehari dengan kecepatan 3 hingga 4 mil per jam, ditambah aktivitas ringan;

3. Aktif, melakukan aktivitas fisik yang setara dengan berjalan lebih dari 3 mil per hari dengan kecepatan 3 hingga 4 mil per jam, ditambah aktivitas fisik ringan. ${ }^{(7)}$

Tabel 2. Klasifikasi Kebutuhan Kalori Berdasarkan Tingkatan Aktivitas Fisik

\begin{tabular}{|c|c|c|c|c|}
\hline \multirow{2}{*}{$\begin{array}{l}\text { Jenis } \\
\text { Kelamin }\end{array}$} & \multirow{2}{*}{$\begin{array}{l}\text { Umur } \\
\text { (Tahun) }\end{array}$} & \multicolumn{3}{|c|}{$\begin{array}{c}\text { Kebutuhan Kalori untuk Tiap } \\
\text { Aktivitas Fisik }\end{array}$} \\
\hline & & $\begin{array}{c}\text { Tidak } \\
\text { Bergerak } \\
\end{array}$ & $\begin{array}{l}\text { Cukup } \\
\text { Aktif }\end{array}$ & Aktif \\
\hline \multirow{3}{*}{ Wanita } & $19-30$ & 2.000 & $\begin{array}{l}2.000- \\
2.200\end{array}$ & 2.400 \\
\hline & $31-50$ & 1.800 & 2.000 & 2.200 \\
\hline & $51+$ & 1.600 & 1.800 & $\begin{array}{l}2.000- \\
2.200 \\
\end{array}$ \\
\hline \multirow{3}{*}{ Pria } & $19-30$ & 2.400 & $\begin{array}{l}2.600- \\
2.800\end{array}$ & 3.000 \\
\hline & $31-50$ & 2.200 & $\begin{array}{l}2.400- \\
2.600\end{array}$ & $\begin{array}{l}2.800- \\
3.000 \\
\end{array}$ \\
\hline & $51+$ & 2.000 & $\begin{array}{l}2.200- \\
2.400\end{array}$ & $\begin{array}{l}2.400- \\
2.800\end{array}$ \\
\hline
\end{tabular}

Ada beberapa langkah untuk merubah kebiasaan pola makan sehari-hari yang direkomendasikan oleh DASH:
1. Tambahkan satu porsi sayuran saat makan siang pada hari pertama dan pada makan malam di hari berikutnya, dan tambahkan buah pada makanan atau sebagai cemilan.

2. Tingkatkan penggunaan produk susu bebas lemak dan rendah lemak hingga tiga porsi sehari.

3. Batasi daging tanpa lemak hingga 6 ons sehari atau 3 ons sekali makan. Jika biasanya makan daging dalam jumlah yang besar, kurangin konsumsi daging dalam beberapa hari, misalnya setengah atau sepertiga setiap kali makan.

4. Sertakan dua atau lebih gaya makan vegetarian, atau tanpa daging, setiap minggu.

5. Tambahkan porsi sayuran, nasi merah, pasta gandum, dan kacang kering yang dimasak. Cobalah hidangan tumis yang mengandung lebih sedikit daging dan lebih banyak sayuran, bijibiian, dan kacang kering.

6. Untuk cemilan dan makanan penutup, gunakan buah-buahan atau makanan lain yang rendah lemak jenuh, lemak trans, kolesterol, natrium, gula, dan kalori, misalnya kue beras tanpa garam, Kacang-kacangan tanpa garam, kismis, crackers, yogurt bebas atau rendah lemak maupun yogurt beku, popcorn tanpa ditambahkan garam atau mentega, atau sayuran mentah.

7. Gunakan sayuran segar atau sayuran kaleng rendah sodium dan buah-buahan. ${ }^{(7)}$

Tabel 3. Daftar Rencana Makan DASH

\begin{tabular}{|c|c|c|c|c|c|c|}
\hline \multirow{2}{*}{$\begin{array}{c}\text { Kelompo } \\
\mathrm{k} \\
\text { Makanan }\end{array}$} & \multicolumn{3}{|c|}{ Sajian Per Hari } & \multirow{2}{*}{ Ukuran Sajian } & \multirow{2}{*}{ Contoh dan Catatan } & \multirow{2}{*}{$\begin{array}{l}\text { Kandungan tiap } \\
\text { Kelompok Makanan } \\
\text { pada Rencana } \\
\text { Makanan DASH } \\
\end{array}$} \\
\hline & $\begin{array}{l}1.600 \\
\text { Kalori }\end{array}$ & $\begin{array}{l}2.000 \\
\text { Kalori } \\
\end{array}$ & $\begin{array}{l}2.600 \\
\text { Kalori }\end{array}$ & & & \\
\hline $\begin{array}{l}\text { Produk } \\
\text { gandum }\end{array}$ & 6 & 6-8 & $10-11$ & $\begin{array}{c}1 \text { potong roti } \\
30 \text { gram sereal kering } \\
1 / 2 \text { mangkuk nasi, pasta, } \\
\text { atau sereal }\end{array}$ & $\begin{array}{c}\text { Roti gandum, pasta } \\
\text { gandum, roti, sereal, bubur } \\
\text { jagung, oatmeal, beras } \\
\text { merah, popcorn. }\end{array}$ & $\begin{array}{l}\text { Sumber utama energy } \\
\text { dan serat. }\end{array}$ \\
\hline Sayuran & $3-4$ & $4-5$ & $5-6$ & $\begin{array}{l}1 \text { mangkuk sayur mentah } \\
1 / 2 \text { mangkuk sayur matang } \\
1 / 2 \text { gelas jus sayuran }\end{array}$ & $\begin{array}{l}\text { Brokoli, wortel, kacang } \\
\text { hijau, kacang polong, } \\
\text { kacang, kentang, bayam, } \\
\text { labu, ubi jalar, tomat. }\end{array}$ & $\begin{array}{c}\text { Sumber kaya } \\
\text { potassium, } \\
\text { magnesium, dan serat }\end{array}$ \\
\hline $\begin{array}{l}\text { Buah- } \\
\text { buahan }\end{array}$ & 4 & $4-5$ & $5-6$ & $\begin{array}{c}1 \text { buah segar } \\
1 / 4 \text { mangkuk buah kering } \\
1 / 2 \text { mangkuk buah kalengan } \\
1 / 2 \text { gelas jus buah segar }\end{array}$ & $\begin{array}{c}\text { Apel, pisang, kurma, } \\
\text { anggur, juruk, jus anggur, } \\
\text { manga, melon, persik, } \\
\text { nanas, kismis, stroberi, } \\
\text { jeruk peras. }\end{array}$ & $\begin{array}{l}\text { Sumber kalium, } \\
\text { magnesium, dan serat }\end{array}$ \\
\hline $\begin{array}{l}\text { Produk } \\
\text { susu } \\
\text { bebas } \\
\text { lemak } \\
\text { atau } \\
\text { rendah } \\
\text { lemak } \\
\end{array}$ & $2-3$ & $2-3$ & 3 & $\begin{array}{l}1 \text { gelas susu atau yogurt } \\
40 \text { gram keju }\end{array}$ & $\begin{array}{c}\text { Susu tanpa lemak (skim) } \\
\text { atau rendah lemak (1\%), } \\
\text { keju bebas lemak atau } \\
\text { rendah lemak, yogurt } \\
\text { bebas lemak atau rendah } \\
\text { lemak. }\end{array}$ & $\begin{array}{l}\text { Sumber utama kalsium } \\
\text { dan protein }\end{array}$ \\
\hline
\end{tabular}




\begin{tabular}{|c|c|c|c|c|c|c|}
\hline $\begin{array}{l}\text { Daging } \\
\text { tanpa } \\
\text { lemak, } \\
\text { unggas, } \\
\text { dan ikan }\end{array}$ & $3-6$ & $\leq 6$ & 6 & $\begin{array}{c}30 \text { gram daging, unggas, } \\
\text { atau ikan } \\
1 \text { butir telur }\end{array}$ & $\begin{array}{l}\text { Daging tanpa lemak } \\
\text { panggang atau rebus; } \\
\text { membuang kulit unggas }\end{array}$ & $\begin{array}{l}\text { Kaya akan sumber } \\
\text { protein dan } \\
\text { magnesium }\end{array}$ \\
\hline $\begin{array}{l}\text { Kacang- } \\
\text { kacangan }\end{array}$ & $\begin{array}{l}3 \text { per } \\
\text { minggu }\end{array}$ & $\begin{array}{l}4-5 \text { per } \\
\text { minggu }\end{array}$ & 1 & $\begin{array}{c}40 \text { gram kacang-kacangan } \\
2 \text { sendok makan selai } \\
\text { kacang }\end{array}$ & $\begin{array}{l}\text { Almond, hazelnut, kacang } \\
\text { tanah, kenari, biji bunga } \\
\text { matahari, selai kacang, } \\
\text { kacang merah, kacang } \\
\text { polong. }\end{array}$ & $\begin{array}{l}\text { Sumber energi, } \\
\text { magnesium, protein, } \\
\text { dan kaya serat }\end{array}$ \\
\hline $\begin{array}{l}\text { Lemak } \\
\text { dan } \\
\text { minyak }\end{array}$ & 2 & $2-3$ & 3 & $\begin{array}{c}1 \text { sendok teh margarin } \\
1 \text { sendok makan minyak } \\
\text { sayur } \\
1 \text { sendok makan } \\
\text { mayonnaise } \\
2 \text { sendok makan saus salad }\end{array}$ & $\begin{array}{l}\text { Margarin, minyak sayur } \\
\text { (seperti kanola, jagung, } \\
\text { zaitun), mayones rendah } \\
\text { lemak, saus salad }\end{array}$ & $\begin{array}{l}\text { Studi DASH memiliki } \\
27 \% \text { kalori sebagai } \\
\text { lemak, termasuk lemak } \\
\text { didalam makanan atau } \\
\text { lemak tambahan ke } \\
\text { makanan }\end{array}$ \\
\hline $\begin{array}{l}\text { Makanan } \\
\text { manis dan } \\
\text { gula } \\
\text { tambahan } \\
\end{array}$ & 0 & $\begin{array}{l}\leq 5 \text { per } \\
\text { minggu }\end{array}$ & $\leq 2$ & $\begin{array}{c}\text { sendok makan gula, jelly } \\
\text { atau selai } \\
1 / 2 \text { gelas agar } \\
1 \text { gelas air limun } \\
\end{array}$ & $\begin{array}{l}\text { Agar rasa buah, buah } \\
\text { tusuk, permen, jelly, sirup } \\
\text { maple, gula. }\end{array}$ & $\begin{array}{l}\text { Permen harus rendah } \\
\text { lemak }\end{array}$ \\
\hline
\end{tabular}

Sebuah studi systematic review dan metaanalysis dari semua randomized controlled trials (RCTs) hingga tahun 2013 pada 2561 partisipan, yang mengevaluasi efek dari diet DASH pada tekanan darah menunjukkan bahwa diet DASH menurunkan tekanan darah sistolik secara signifikan sebesar $6,74 \mathrm{mmHg}$ dan tekanan darah diastolik sebesar 3,54 mmHg. Hasil ini mengungkapkan efek pengurangan yang menguntungkan dari diet DASH pada tekanan darah sistolik dan diastolik pada orang dewasa. ${ }^{(18)}$ Studi systematic review dan meta-analysis dari RCTs yang lain membahas tentang efek diet DASH terhadap berat badan orang dewasa mengungkapkan bahwa orang dewasa yang menjalani diet DASH kehilangan lebih banyak berat badan sebesar $1,42 \mathrm{~kg}$ dalam 8-24 minggu dibandingkan dengan kelompok kontrol. Diet DASH rendah kalori menyebabkan penurunan berat badan lebih banyak dibandingkan dengan diet rendah kalori lainnya. Selain itu efeknya lebih besar pada pasien yang kelebihan berat badan/obesitas jika dibandingkan dengan diet lainnya. Sehingga siet DASH merupakan pilihan yang baik untuk menurunkan berat badan terutama pada seseorang yang memiliki kelebihan berat badan atau obesitas. ${ }^{(19)}$

\section{KESIMPULAN}

Diet DASH sangat membantu dalam menurunkan hipertensi atau tekanan darah tinggi pada orang dewasa. Penurunan tekanan darah yang dihasilkan dari penerapan diet DASH dapat mencapai 8-14 mmHg. Diet DASH dapat digunakan sebagai terapi nonfarmakologis yaitu berupa modifikasi gaya hidup dengan cara mengatur pola makan dengan banyak makan makanan yang kaya akan sayuran, buah-buahan, susu dan produk-produk susu tanpa lemak atau rendah lemak, biji-bijian, ikan, unggas, kacang-kacangan, seta mengandung sedikit natrium, makanan manis, gula, lemak, dan daging merah.

\section{DAFTAR PUSTAKA}

1. Martono H. Buku Ajar Geriatri. Jakarta: FKUI; 2010.

2. Ismalia N, Zuraida R. Efek tomat (Lycopersion esculentum Mill) dalam menurunkan tekanan darah tinggi. MAJORITY. 2016; 5(4):107-111.

3. Chobanian AV, Bakris GL, Black HR, et all. The Seventh Report of the Joint National Committee on Prevention, Detection, Evaluation, and Treatment of High Blood Pressure. Hypertension. 2003; 42:1206-52.

4. Kemenkes RI. Hasil utama Riskesdas 2018. Jakarta: Balitbang Kemenkes RI; 2018. 82-88 p.

5. Arifa AFC. Pengaruh informasi pelayanan prolanis dan kesesuaian waktu terhadap pemanfaatan prolanis di pusat layanan kesehatan Unair. JAKI. 2018; 6(2): 95-102.

6. PERKI. Pedoman Tatalaksana Hipertensi pada Penyakit Kardiovaskular. Edisi I. Jakarta: Perhimpunan Dokter Spesialis Kardiovaskular Indonesia; 2015.

7. National Heart, Lung, and Blood Institute. Your Guide to Lowering Your Blood Pressure With DASH [Internet]. National Institutes of Health. 2006 [cited 2019 Dec 2]. p. 64-1. Available from: https://www.nhlbi.nih.gov/files/docs/public/heart/ new dash.pdf

8. Annisa R, Wardaningsih S, Sari NK. Strategi self-management untuk meningkatkan professional behaviors. MEDISAINS. 2017; 15(3): 129-35.

9. Moniaga, V, Pangemanan, D. H. C., Rampengan, J. J. V. Pengaruh Senam Bugar Lansia terhadap 
Tekanan Darah Penderita Hipertensi di BPLU Senja Cerah Paniki Bawah. Jurnal e-Biomedik. Vol. 1. No. 2. Juli 2013:785-789

10. Zulfikri M. Perubahan Hemodinamik dan Terapi Hipertensi dari Aspek Kardiovaskuler. 1996. 2425.

11. Sheldon G. Sheps. Mayo Clinic Hipertension. 2005;26.

12. Suri, Atika. (2017). Efektivitas Senam Tai Chi Terhadap Penurunan Tekanan Darah Pada Lanjut Usia Dengan Riwayat Hipertensi Di Puskesmas Junrejo Kota Batu. Naskah Publikasi.Fakultas Ilmu Kesehatan Univeristas Muhammadiyah Malang.

13. Sudoyo AW, Setiyohadi B, Alwi I, Simadibrata M, Setiati S. Buku Ajar Ilmu Penyakit Dalam Jilid II. Edisi V. Jakarta: Interna Publishing; 2015. 2261-2 p.

14. Kaplan NM. Primary hypertension: pathogenesis. Kaplan's clinical hypertension. 10th ed. Philadelphia: Lippincott Williams \& Wilkins; 2010. 44-108 p.

15. European Society of Hypertension - European Society of Cardiology Guidelines Committee. 2003 European Society of Hypertension European Society of Cardiology Guidelines for the Management of Arterial Hypertension. J Hypertens. 2003; 21:1011-53.

16. Lewington S, Clarke R, Qizilbash N, et al. Agespecific relevance of usual blood pressure to vascular mortality: a meta-analysis of individual data for one million adults in 61 prospective studies. Lancet. 2002; 360: 1903-13.

17. Muhadi. JNC 8: Evidence-based Guideline Penanganan pasien hipertensi dewasa. CDK. 2016; 43(1):54-9.

18. Saneei P, Salehi AA, Esmaillzadeh A, Azadbakht L. Influence of Dietary Approaches to Stop Hypertension (DASH) diet on blood pressure: a systematic review and meta-analysis on randomized controlled trials. Nutr Metab Cardiovasc Dis. 2014; 24(12):1253-61.

19. Soltani S, Shirani F, Chitsazi MJ, Salehi AA. The effect of dietary approaches to stop hypertension (DASH) diet on weight and body compostion in adults: a systematic review and meta-analysis of randomized controlled clinical trials. Obes Rev. 2016; 17(5):442-54. 